\title{
Design activism from the past to present: A critical analysis of the discourse
}

\author{
Ozgur Deniz Cetin / Izmir Institute of Technology / Izmir / Turkey
}

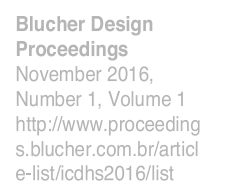

\begin{abstract}
The primary objectives of this study are to explore the different phases of design activism in its forty five years of history, and to examine the ideology and structure that lie behind the discourse. The theoretical framework of this study postulates design activism as a movement within the design community which stems from mainstream social movements opposed to socioeconomic developments of the twentieth century. The method of the study employs Critical Discourse Analysis on design activism discourse, with a focus on industrial design. A sample group of publications is selected and analysed through CDA to reveal the historical progress of design activism discourse and to provide insights into the content, as well as the contexts design activism exists in, and the strategies formulated to achieve the movement's objectives. The results are critically interpreted, and the deficiencies of design activism are discussed in furtherance of design activism movement.
\end{abstract}

\section{Keywords}

Design Activism, Design Discourse, Design History

\section{Introduction}

Design activism indicates, in Julier's (2011) words, "a voluntarist, politically motivated impetus: a desire for amelioration, to make a better world", and design activism has grown recently, in parallel with awareness of global environmental, social, political, and economic issues (p.1). Fuad-Luke (2009) introduces a preliminary definition of design activism as, "design thinking, imagination and practice applied knowingly or unknowingly, to create a counternarrative aimed at generating and balancing positive social, institutional, environmental and/or economic change" ( $p$. 27). Design activism serves as an umbrella term that incorporates many design approaches which share the aims defined. Despite the increasing interest by design community, the rising number of organizations and activities (FuadLuke, 2009), and growing number of academic publications, the outcomes of design activism are almost invisible, not only for public audience, but even for design community itself.

The main motivation for this study is to thoroughly comprehend design activism through a critical analysis of its discourse which has evidential value regarding the ideology, epistemology, and ontology of the concept. Exploring the different phases of design activism in its forty-five year history is another objective of this study. Although the extent of design activism affects most design disciplines, the scope of this study is limited to the discourse associated with industrial design discipline.

\section{Historical context of design activism}

Design activism subject has often been discussed throughout the extensive history of design, dating back to William Morris and design reform movement (Fuad-Luke, 2009; Julier, 2011). In some studies, design activism is also referred as a design movement (Clarke, 2013; Julier, 2013). Further to that, this study postulates design activism specifically as a social movement. This is based on the premise that the roots of design activism rest upon the social processes and social movements which emerged as results of the processes of change, namely advanced industrialization and globalization, in the second half of the twentieth century.

According to Jordan (2002), before the 1960s social movements were based on class struggles, and they were considered as extremist, destructive and vicious. However, in the 1960s, general framework of 
social movements shifted to equally important, but more diversified political struggles (Jordan, 2002). Therefore, their significance for society and attitude towards social movements have changed. Tarrow (2011) places social movements within the sphere of contentious politics, whereby ordinary people join forces to confront authorities, elites and powerful opponents. He defines social movements as “... collective challenges, based on common purposes and social solidarities, in sustained interaction with elites, opponents, and authorities. This definition has four empirical properties: collective challenge, common purpose, social solidarity, and sustained interaction" (p.9). According to Julier (2013), design activism has arisen as a movement contesting the structures and processes of neoliberalism which have dominated the planet for thirty years. Hereby, this study conceives design activism is a social movement.

At this juncture, Karl Polanyi's "double movement" theory, depicted in The Great Transformation (1944), is valuable in understanding the social, political, and economic complexity of our time. Briefly, Polanyi's proposal is of a two-phase movement, first marketization, and following of social movements for self-protection (Udayagiri \& Walton, 2003). This theory provides the basis for an interpretation of globalization and its global countermovements in the last decades. In consequence, design activism movement can be seen as a relatively moderate and still a contentious manifestation of concurrent mainstream social movements - against industrialization, and globalization - within design profession. There have been many notable critiques of the consequences of industrialization, and industrial society (marketization, in Polanyi's terms) in the late 1950s and during the 1960s, including those of Vance Packard, Ralph Nader, and Herbert Marcuse (Lang \& Gabriel, 2005; Marcuse, 2002; Whiteley, 1987). Yet, the first critique directly associated with industrial design profession did not arrive until Victor Papanek's seminal book Design for the Real World (1971). For this reason, this study posits Papanek's book as the inception of design activism discourse.

\section{The analysis of design activism discourse}

Critical Discourse Analysis (CDA) approach is used to analyse design activism discourse over a sample group of publications. The aim is to combine a micro-level textual analysis with meso and macro-level intertextual analyses which draw attention to wider discursive frameworks, and to reveal broader elements shaping the texts (Fairclough, 1995). According to Wodak and Meyer (2001), CDA assumes that all discourses are historical; they can only be understood in connection with their own context. Discourses are also ideological; therefore their manifestations and remarks are not arbitrary. CDA attempts to explain the genesis and the structure of a discourse, and to disclose power relationships that are generally hidden, thus allowing conclusions that can be practical and relevant (Wodak \& Meyer, 2001). In this case, CDA is an effective method for disclosing the power relationships between industrial design profession, and politics, economics, society, and environment. Although a multidisciplinary approach may reveal the historical context and development of design activism discourse, the scope of this study is limited to industrial design field. Therefore, the analysed materials within this study belong to industrial design domain.

After an overall literature review the fundamental concepts of design activism discourse were clarified. Primary resources that are leading the discourse and defining the concepts of design activism are selected. Based on the fundamental definitions and explanations of the design activism concept, further materials that match with the framework of design activism concept are sought for analysis. By going backwards towards the material cited in those resources, and by going forward towards the materials that cited primary resources on the discourse, a pool of resources is gathered via an on- going process throughout the analysis along with the substantive database search.

A hundred and twenty two publications are examined thoroughly and a set of resources was identified for the further analysis of design activism discourse. Three criteria for the filtering of the examined resources were; the date of the publication; between the years of 1971 and 2015, the type of publication; published books, journals articles, conference proceedings, and the field of design that the publication is related to; which is industrial design. The sample group for analysis comprises sixty three resources (Table 1).

Three ground levels of the critical analysis in this study can be explained as follows: 1) The content; how the approach is termed and identified and what constitutes design activism discourse: 2) The context of the discourse; in which context design activism is discussed: and 3) The plan for design activism; what the course of action is in order to achieve the main subjective of the approach. The content of the analysed materials are deeply studied and scanned by using linguistic instruments - such as detecting the repeating terms or mentions - to find out clarifications regarding these three steps. The findings of the analysis are presented in the following sections. 


\section{Historical progress of design activ- ism discourse}

In 1971, Papanek's book inflamed the debates about social, economic, and environmental consequences of design profession. The following discussions, for instance, 1976 "Design for Need" Conference organized by International Council of Societies of Industrial Design (Fuad-Luke, 2009), laid the groundwork for design activism discourse. Therefore, 1970s can be regarded as the genesis of design activism.

In the 1980s, while globalization was rapidly progressing, new economy politics like "Design for Profit" campaign in the UK (Madge, 1993) was steering the design profession. Another factor is the dominancy of post-modernism within design community at the time. Thus, activist design approaches were scarcely found in the 1980s, which can be defined as the hibernation period of the design activism. The 1990s witnessed the awakening of design activism discourse. Concerns for the future societies became incorporated into the design discourse when environmental and social crises appeared critical, such as sustainability (Madge, 1997). In this revival phase, activist approaches reasserted their position in the design community.

During the 2000s, numerous design networks and organizations concerned with social, economic, and environmental problems were formed (Julier, 2013; Thorpe, 2012). With such a growth, it can justifiably be argued that design activism had proceeded to the next phase. Thus, this decade can be described as the growth phase of design activism.

Finally, design activism discourse significantly expands in terms of number of publications in the 2010s. The boom of the discourse signifies the establishment of design activism as a key issue in the design community, and this period can be depicted as the period of maturity and steady growth.

Figure 1 presents the development process of design activism discourse based on the analysis of sample group.

\section{The Substance Of Design Activism}

Four distinct topics come to the fore in design activism discourse; social issues, economic issues, political issues, and environmental issues. Figure 2 displays the historical disper-

\begin{tabular}{|c|c|c|}
\hline \multicolumn{3}{|l|}{ ARTICLES } \\
\hline Precariousness and ambiguity: Industrial design in dependent countries & Gui Bonsiepe & 1977 \\
\hline Designing for need -radio talk & Peter Lloyd Jones & 1977 \\
\hline Twelve methodologies for design - Because people count & Victor Papanek & 1977 \\
\hline The coming of post-industrial design & Nigel Cross & 1981 \\
\hline Understanding the role of the designer in society & Jill Grant, Frank Fox & 1992 \\
\hline $\begin{array}{l}\text { Prometheus of the Everyday: The Ecology of the Artificial and the } \\
\text { Designer's Responsibility }\end{array}$ & $\begin{array}{l}\text { Ezio Manzini, } \\
\text { John Cullars }\end{array}$ & 1992 \\
\hline $\begin{array}{l}\text { Design, Environment and Social Quality: From" Existenzminimum" to" } \\
\text { Quality Maximum" }\end{array}$ & Ezio Manzini & 1994 \\
\hline Design for a Sustainable World & Victor Margolin & 1998 \\
\hline $\begin{array}{l}\text { Human dignity and human rights: Thoughts on the principles of human- } \\
\text { centered design }\end{array}$ & Richard Buchanan & 2001 \\
\hline A “Social Model” Of Design: Issues Of Practice And Research & $\begin{array}{l}\text { Victor Margolin, } \\
\text { Sylvia Margolin }\end{array}$ & 2002 \\
\hline Rethinking Design Policy in the Third World & Sulfikar Amir & 2004 \\
\hline Alternative design scholarship: Working toward appropriate design & Dean Nieusma & 2004 \\
\hline $\begin{array}{l}\text { Design by Society: Science and Technology Studies and the Social } \\
\text { Shaping of Design }\end{array}$ & $\begin{array}{l}\text { Edward Woodhouse, } \\
\text { Jason W. Patton }\end{array}$ & 2004 \\
\hline The challenge of responsible design & Jesse S. Tatum & 2004 \\
\hline $\begin{array}{l}\text { Rethinking Design Education For The 21st Century: Theoretical, } \\
\text { Methodological, And Ethical Discussion }\end{array}$ & Alain Findeli & 2005 \\
\hline Ethics and altruism: what constitutes socially responsible design? & Rachel Cooper & 2005 \\
\hline Altruism as design methodology & David Stairs & 2005 \\
\hline Design and Democracy & Gui Bonsiepe & 2006 \\
\hline $\begin{array}{l}\text { Social Innovation And New Industrial Contexts: Can Designers } \\
\text { "Industrialize" Socially Responsible Solutions? }\end{array}$ & Nicola Morelli & 2007 \\
\hline $\begin{array}{l}\text { Problems or Opportunities?: Overcoming the Mental Barrier for Socially } \\
\text { Responsible Design in Turkey }\end{array}$ & $\begin{array}{l}\text { Özlem Er, } \\
\text { Çiğdem Kaya }\end{array}$ & 2008 \\
\hline Design for development: A capability approach & Ilse Oosterlaken & 2009 \\
\hline Design's role in sustainable consumption & Ann Thorpe & 2010 \\
\hline Design Thinking for Social Innovation & $\begin{array}{l}\text { Tim Brown, } \\
\text { Jocelyn Wyatt }\end{array}$ & 2010 \\
\hline $\begin{array}{l}\text { Small, local, open and connected, Design for social innovation and } \\
\text { sustainability }\end{array}$ & Ezio Manzini & 2010 \\
\hline $\begin{array}{l}\text { Socially responsible design: Thinking beyond the triple bottom line to } \\
\text { socially responsive and sustainable product design }\end{array}$ & $\begin{array}{l}\text { Gavin Melles, Ian de } \\
\text { Vere, Vanja Misic }\end{array}$ & 2011 \\
\hline Poland Welcomes a World of Socially Responsible Design & Beata Bochińska & 2011 \\
\hline $\begin{array}{l}\text { The Urban Precariat, Neoliberalization, and the Soft Power of } \\
\text { Humanitarian Design }\end{array}$ & Cedric. G. Johnson & 2011 \\
\hline Design with society: why socially responsive design is good enough & $\begin{array}{l}\text { Adam Thorpe, } \\
\text { Lorraine Gamman }\end{array}$ & 2011 \\
\hline Nothing Special? (Activist) Design Skills for the 21st Century & Guy Julier & 2012 \\
\hline Reflections on Design Activism and Social Change. & Grace Lees-Maffei & 2012 \\
\hline Design for social innovation: emerging principles and approaches & Anne Chick & 2012 \\
\hline $\begin{array}{l}\text { "Actions Speak Louder": Victor Papanek and the Legacy of Design } \\
\text { Activism }\end{array}$ & Alison J. Clarke & 2013 \\
\hline From Design Culture to Design Activism & Guy Julier & 2013 \\
\hline Global Design Activism Survey & $\begin{array}{l}\text { Harun Kaygan, } \\
\text { Guy Julier }\end{array}$ & 2013 \\
\hline Material Preference and Design Activism & Guy Julier & 2013 \\
\hline $\begin{array}{l}\text { Empathy or inclusion: A dialogical approach to socially responsible } \\
\text { design }\end{array}$ & $\begin{array}{l}\text { Carla Cipolla, } \\
\text { Roberto Bartholo }\end{array}$ & 2014 \\
\hline $\begin{array}{l}\text { Designing Development: Humanitarian Design in the Financial Inclusion } \\
\text { Assemblage }\end{array}$ & Anke Schwittay & 2014 \\
\hline Critical making as materializing the politics of design & Carlo DiSalvo & 2014 \\
\hline \multicolumn{3}{|l|}{ BOOKS } \\
\hline Design for the real world; Human ecology and social change & Victor Papanek & 1972 \\
\hline Design for society & Nigel Whiteley & 1993 \\
\hline The green imperative: Ecology and ethics in design and architecture & Victor Papanek & 1995 \\
\hline Design for micro-utopias : making the unthinkable possible & John Wood & 2007 \\
\hline Design revolution : 100 products that empower people & Emily Pilloton & 2009 \\
\hline Design activism: beautiful strangeness for a sustainable world & Alastair Fuad-Luke & 2009 \\
\hline Design as politics & Tony Fry & 2011 \\
\hline $\begin{array}{l}\text { Architecture and design versus consumerism: How design activism } \\
\text { confronts growth }\end{array}$ & Ann Thorpe & 2012 \\
\hline $\begin{array}{l}\text { Social Design: How products and services can help us act in ways that } \\
\text { benefit society }\end{array}$ & Nynke Tromp & 2013 \\
\hline
\end{tabular}

\section{PROCEEDINGS}

\begin{tabular}{|l|l|c|}
\hline \multicolumn{2}{|c|}{$\begin{array}{l}\text { Design for Social Responsibility and Market Oriented Design: } \\
\text { Convergences and Divergences }\end{array}$} & Nicola Morelli \\
\hline $\begin{array}{l}\text { Design for the Surreal World. A New Model of Socially Responsible } \\
\text { Design }\end{array}$ & Davey et al. & 2003 \\
\hline $\begin{array}{l}\text { Design Against Crime: Design leadership in the development of emotional } \\
\text { values }\end{array}$ & Davey et al. & 2005 \\
\hline Sustainable and humanitarian design education & Ursula Tischner & 2006 \\
\hline Design as activism: A conceptual tool & Ann Thorpe & 2008 \\
\hline Design for humanity in the century of famine and warfare & Alkn Korkmaz & 2009 \\
\hline Everyday People: Enabling User Expertise in Socially Responsible Design & $\begin{array}{l}\text { Christine Caruso, } \\
\text { Lois Frankel }\end{array}$ & 2010 \\
\hline Political Economies of Design Activism and the Public Sector & Guy Julier & 2011 \\
\hline $\begin{array}{l}\text { Designing with a social conscience: An emerging area in industrial design } \\
\text { education and practice }\end{array}$ & Mariano Ramirez Jr & 2011 \\
\hline $\begin{array}{l}\text { From the Industrial Revolution to the Era of Ideas: Emergence of } \\
\text { "Anarchism of the Object" }\end{array}$ & $\begin{array}{l}\text { Juan Gasca Rubio, } \\
\text { Daniel Collado-Ruiz }\end{array}$ & 2011 \\
\hline Designing Anti-Activism: Apocalypse faster! & Tatu Marttila & 2011 \\
\hline DESIS-Africa: Design Thinking For Social Innovation and Development & Ambole et al. & 2012 \\
\hline $\begin{array}{l}\text { Can design go beyond critique?: trying to compose together in opening } \\
\text { production. }\end{array}$ & Anna Seravalli & 2013 \\
\hline Achieving responsible design within the commercial remit. & Stevenson et al. & 2014 \\
\hline Our Common Future? Political questions for designing social innovation & Ramia Mazé & 2014 \\
\hline Social Design Principles and Practices & $\begin{array}{l}\text { Inês Veiga, } \\
\text { Rita Almendra }\end{array}$ & 2014 \\
\hline
\end{tabular}

Table 1: Sample group 


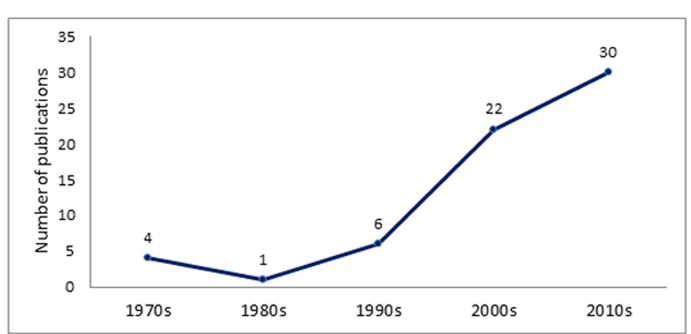

Figure 1: Historical flow of the design activism discourse

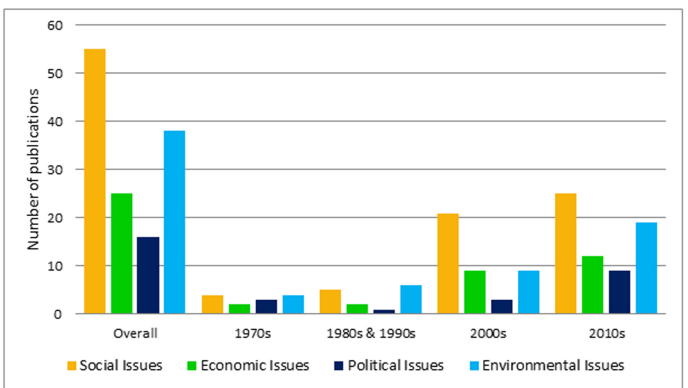

Figure 2: Historical dispersion of the subject matters within the design activism discourse

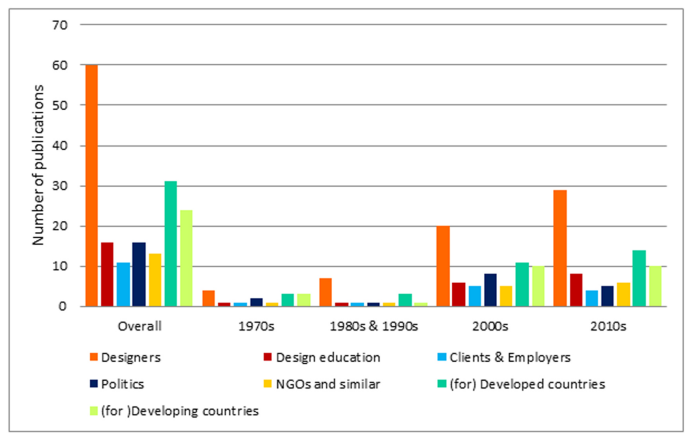

Figure 3: Historical dispersion of the context within the design activism discourse sion and distribution of these topics.

Social issues are the most frequent subjects among the discourse. This topic incorporates the increase in the social welfare state in local or global contexts, bringing positive social change, and satisfying the needs of neglected segments of society, including the elderly, handicapped, and the poor. Following social issues in design activism discourse are environmental issues, covering overall arguments regarding sustainability, limited natural resources, global warming, preservation of habitats and ecology, and particularly, their relation with design. Economic issues are the third most frequently addressed issues. This area relates to the socially adverse and destructive outcomes of the economic phenomena such as capitalism, neoliberalism and globalization; social stratification, consumerism, and the designer's role in the context of these economic phenomena.

Political issues are much less common in design activism discourse compared to other topics. The relationship between politics and the social, economic, and environmental problems referred in the discourse forms the content of the political issues. Notable topics include the role of design in development strategies and policies, and the regulations which ultimately shape the industrial design practice.

In order to analyse the context in which design activism is discussed, the figures, institutions, and organizations addressed within the discourse are described and discussed. Almost all of the sources discuss design activism within the context of designers' own practices. However, design activism is mostly contextualized in multiple contexts, shown in figure 3.

Design education's inadequacy to provide designers with necessary skills to cope with social, cultural, environmental issues etc. is another context addressed within design activism discourse. The relationship with clients and employers, those who make

the final decisions for the realization of designed product or service, is the least considered context within design activism discourse. Only one quarter of the sample group postulate that design activism is relevant to politics, which indicates the lack of concern over the role and the relationship of designers with local governments, policy makers, legislations, and public service policies. Again, only one quarter of the sample group consider that NGOs and similar organizations provide designers with an adequate course for activist practices.

Regarding the geographical context of design activism, half of the sources approach the subject in the context of developed countries, in which the primary focus is the struggle with destructive consequences of design decisions in developed countries. On the other hand, fewer sources consider design activism within the context of developing countries. The main approach in this context, in general, can be described as seeking to overcome the existing problems and empowering societies through design.

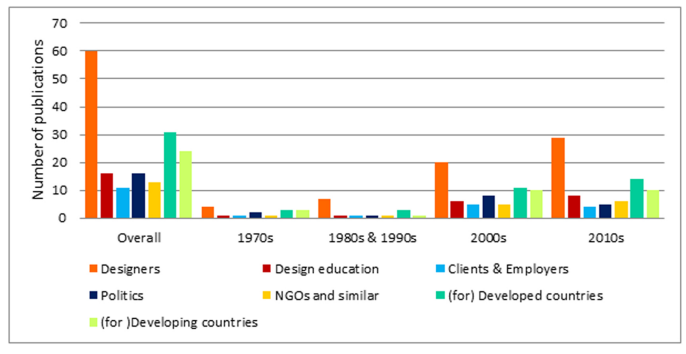

Figure 4: Historical dispersion of the course of actions within the design activism discourse

\section{The Course of Design Activism}

According to the analysis, design activism discourse comprises four main strategies to achieve its objectives; "designers' initiative", "opportunities in economic order", "design as politics", and "design in the local context", presented in Figure 4.

"Designers' initiative" implies the necessity to consider social, economic, environmental, and political conditions while designing a product or a service. "Designers' initiative" is the most frequently formulated method to achieve design activism's 
objectives, and can be typically exemplified with Papanek's (1971) approach, which triggered the discourse.

The second most commonly proposed approach is "design in the local context". This aims to establish design-driven operations which act at least partially, if not fully, outside economic rationale, in order to generate social, environmental, and economic benefits in particular locality. John Wood's (2007) and Ezio Manzini's (2010) publications are examplary in this manner.

The opportunities concealed in contemporary economic order for activist designers is another proposed approach for achieving the objectives of design activism. This approach suggests that the neo-liberal economic structure allows designers to bring about positive change, especially in the public sector. Margolin \& Margolin's (2002) and Julier's (2011) apporaches are good examples of this argument.

"Design as politics" implies change in policies and strategies related with design and productions of goods, services and systems that affect social, economic, and environmetal conditions. Bonsiepe's (1977) argument entreats a focus on developing, peripheral countries, and Tony Fry's (2011) criticisms on developed countries essentially elucidate this perspective. The analysis suggests that "opportunities in economic order" and "design as politics" are the models that have been considered the least in the achievement of the objectives of design activism (See figure 8).

\section{Conclusion}

In this study, a sample group of texts illustrating design activism discourse was selected and analysed through CDA to reveal the historical progress of design activism discourse, and to provide insights about the subject matters that design activism deals with, as well as the contexts it exists in, and the strategies to achieve its objectives. The analysis results clearly propound that relatively long background leading to the recent rise of design activism should not imply the movement is yet perfectly accomplished and effective. Most arguments within design activism discourse neglect to challenge the established economic and political aspects of the design profession.

In this circumstance, I would argue that design activism's inadequacy is the failure to understand, and perhaps ignorance of the interwoven relationship between the issues and contexts addressed in the discourse. For instance, an approach which attempts to deal only with social issues, such as poverty or inequality, is a vain venture not only for designers, but for any profession or organization. Instead, designers must recognize chain-like interdependency of social, environmental, economic, and political issues. In this regard, politics and economics are major determiners over environmental and social conditions. In today's conjuncture, the influence of politics and economics go far beyond the local or national scale, as it is evident in the case of globalization (McMichael, 2003). Since design activism is arguably the most critical and contentious form of discourse, any lack of scrutiny of economic and political aspects will result in inadequacy in the design profession in general.

Therefore, I argue that "designers' initiative" is an unavailing course of action and it has failed to achieve design activism's objectives. Even though designers are capable of overcoming problems and generating feasible alternatives, the autonomy of design profession remains limited (Julier, 2008; Margolin, 2007). Emphasizing the designers' role and calling them to action is more of a diagnosis than a treatment. In contrast, the other three alternatives strategies are more pragmatic, solution- oriented and more effective models for achieving the desired positive change. "Opportunities in economic order" is an opportunist approach that works through the channels of an existing regime and structure, while "design in the local context" is more of a maverick model aiming to by-pass or act outside of the mainstream economic order (Manzini, 2010). Both are bottom to top approaches, aiming at fragmental change via grass-roots activities. Yet, the potential for change is limited by reason of their restricted contexts, particularly when compared to the global scale of the addressed issues.

On the other hand, a top to bottom model of action may lead to larger scaled positive change. Although politics is a neglected subject within design profession, policies and regulations are crucial with respect to the social, economic, and environmental problems and their solutions. Regulations are the principal mechanisms for restraining markets and destructive outcomes of the market operations. Policies are critical determinants for the markets to drive the competing corporations towards the desired outcomes as they draw the lines for the markets.

Finally, according to Rucht \& Neidhardt (2002), certain movements can be institutionalized as supplementary political interest mediator elements in modern social systems. Rather than substituting political parties or interest groups; they may be able to persuade them to consider their demands. In this respect, "design as politics" is a more far-reaching method compared to the others. Therefore, developing stronger political arguments and institutions is more likely to lead to the achievement of the broad objectives of design activism in the long term. 


\section{References}

Bonsiepe, G. (1977) 'Precariousness and ambiguity: Industrial design in dependent countries' in Bicknell, J. and McQuiston, L. (Ed), Design for need social contribution of design, London: Pergamon Press \& Royal College of Art.

Clarke, A. (2013) 'Actions Speak Louder: Victor Papanek and the legacy of design activism', Design and Culture, vol. 5, no. 2, pp. 151-168.

Fairclough, N. (1995) Critical discourse analysis: the critical study of language. London: Longman. Fry, T. (2011) Design as politics, New York: Berg.

Fuad-Luke, A. (2009) Design activism beautiful strangeness for a sustainable world. London: Earthscan. Jordan, T. (2002) Activism!: Direct action, hactivism and the future of society. London: Reaktion Books.

Julier, G. (2008) The culture of design, $2^{\text {nd }}$ edition, Los Angeles: SAGE.

Julier, G. (2011) 'Political economies of design activism and the public sector' in Koskinen, I., Harkasalmi, T., Maze, R., Matthews, B., and Lee, J. (ed), Nordes 2011 - Making Design Matter. Helsinki, Finland: Aalto University.

Julier, G. (2013) 'From design culture to design activism', Design and Culture, vol. 5, no. 2, pp. 215- 236.

Lang, T. \& Gabriel, Y. (2005) 'A brief history of consumer activism' in Harrison, R., Newholm, T., and Shaw, D. (ed) The ethical consumer, Thousand Oaks: Sage.

Madge, P. (1993) 'Design, ecology, technology: A historiographical review', Journal of Design History, vol. 6, no. 3, pp. 149-166.

Madge, P. (1997) 'Ecological design: a new critique', Design issues, vol. 13, no. 2, pp. 44-54. Margolin, V., \& Margolin, S. (2002) 'A "social model" Of design: Issues of practice and research', Design Issues, vol. 18, no. 4 , pp. 24-30.

Margolin, V. (2007) 'Design, the future and the human spirit', Design Issues, vol. 23, no. 3, pp. 4-15. Manzini, E. (2010) 'Small, local, open and connected, design for social innovation and sustainability', The Journal of Design Strategies, vol. 4, no. 1, pp. 8-11.

Marcuse, H. (2002) One-dimensional man: studies in the ideology of advanced industrial society, $2^{\text {nd }}$ edition, London: Routledge.

McMichael, P. (2003) 'Globalization', in Janoski, T., Alford, R. R., Hicks, A. M., and Schwartz, M. A. (ed) The handbook of political sociology: states, civil societies, and globalization, New York: Cambridge University Press.

Papanek, V. (1971) Design for the real world: Human ecology and social change. New York: Pantheon Books.

Polanyi, K. (1944) The great transformation: The political and economic origins of our time. Boston: Beacon Press.

Rucht, D., \& Neidhardt, F. (2002). 'Towards a "movement society"? On the possibilities of institutionalizing social movements'. Social Movement Studies: Journal of Social, Cultural and Political Protest, vol. 1, no. 1, pp. 7-30.

Tarrow, S. (2011) Power in movement: social movements and contentious politics, New York: Cambridge University Press.

Thorpe, A. (2012) Architecture and design versus consumerism: How design activism confronts growth, Oxon: Earthscan.

Udayagiri, M., \& Walton, J. (2003) 'Global transformation and local counter movements: the prospects for democracy under neoliberalism', International journal of comparative sociology, vol. 44, no. 4, pp.309-343. Whiteley, N. (1987) 'Toward a throw-away culture. Consumerism, "style obsolescence" and cultural theory in the 1950s and 1960s', Oxford Art Journal, vol. 10, no. 2, pp. 3-27.

Wodak, R. and Meyer, M. (2001) Methods of critical discourse analysis. London: SAGE. Wood, J. (2007) Design for micro-utopias: making the unthinkable possible. Aldershot: Gower.

\section{Biographical note}

Ozgur Deniz Cetin is an industrial designer and a Ph.D. student. He was a research/teaching assistant in the Industrial Design Department at Izmir University of Economics for three years, where he assisted design project courses and other applied courses as well. His research interests are design activism and local design initiatives. 